\title{
DIKSI MAJAS OKSIMORON DAN TERJEMAHANNYA DALAM ANTOLOGI PUISI TIDAK ADA NEW YORK HARI INI
}

\author{
I Gusti Agung Sri Rwa Jayantini ${ }^{1}$ dan Ronald Umbas ${ }^{2}$ \\ 1) Prodi Sastra Inggris,STIBA Saraswati Denpasar \\ 2)Prodi Administrasi Negara,STISPOL Wira Bhakti Denpasar \\ email: sri.rwa.jayantini@gmail.com
}

\begin{abstract}
Abstrak
Karya sastra dan penerjemahan mempunyai peran penting dalam perkembangan bahasa. Cara berekspresi dengan menggunakan diksi dalam karya sastra, khususnya puisi dan terjemahannya memberi peluang bagi pengayaan kosa kata dan pendalaman makna. Penelitian ini merupakan kajian penerjemahan puisi yang berfokus pada diksi majas oksimoron. Analisis bertujuan untuk mengetahui jenis antonim dan strategi penerjemahan diksi bertentangan pada antologi puisi Tidak ada New York Hari Ini dan terjemahannya dalam bahasa Inggris. Metode kualitatif diterapkan dengan melakukan pengamatan (observation) dan analisis isi (content analysis) untuk mencermati diksi yang menciptakan nuansa bertentangan. Ada dua hal utama yang menjadi hasil penelitian ini. Pertama, diksi majas oksimoron dapat berupa: (a) oposisi kembar yakni pertentangan mutlak dari dua leksikon, (b) gradual yakni leksikon bertentangan yang menunjukkan gradasi terukur, dan (c) relasional yakni oposisi yang memiliki kaitan hirarkis. Kedua, strategi penerjemahan secara harfiahdan harfiah-makna. Secara harfiah, penerjemahan dilakukan dengan padanan yang makna leksikalnya sesuai, sedangkan secara harfiah-makna penerjemahan dilakukan dengan menggunakan padanan alternatif untuk memberi kesan lebih estetis dan puitis.
\end{abstract}

Kata Kunci: diksi, oksimoron, strategi penerjemahan, penerjemahan puisi

\section{THE DICTION OF THE OXYMORON FIGURE OF SPEECH AND ITS TRANSLATION IN THE POETRY ANTHOLOGY TIDAK ADA NEW YORK HARI INI}

\begin{abstract}
Literary works and translation play a significant role in language development. Expressions through diction in literary works, particularly poems and their translation, can encourage the enrichment of vocabulary and the exploration of meaning. This is a poetry translation study focused on the diction of oxymoron figure of speech. It aims to investigate types of antonyms and strategies used to translate oxymorons to represent the opposite atmosphere in the poetry anthology Tidak Ada New York Hari Ini and its translation in English. The study employed the qualitative method through close observation and content analysis on the diction selected to create a contradictory situation. There are two significant findings. First, oxymorons can be: (a) binary opposition, namely absolute opposition of two words; (b) gradable antonym, namely opposition of words with measurable gradation; and (c) relational antonym,
\end{abstract}


namely opposition with a hierarchical relation. Second, there are two translation strategies, i.e. literal translation and literal-meaning translation. The former is done through close lexical meaning equivalentswhile the latter is done through alternative equivalents to obtain more aesthetic and poetic impressions.

Keywords: diction, oxymoron, translation strategies, poetry translation

\section{PENDAHULUAN}

Diksi merupakan pilihan kata yang digunakan untuk menyampaikan gagasan atau ide secara lisan maupun tulisan. Menurut Kridalaksana (2008: 50) diksi adalah "pilihan kata dan kejelasan lafal untuk memperoleh efek tertentu dalam berbicara di depan umum atau dalam karang mengarang." Diksi tak dapat dilepaskan dari sejumlah aspek dalam linguistik dan sastra seperti fraseologi, gaya bahasa dan ungkapan (Keraf, 2006: 22). Fraseologi sangat dekat kaitannya dengan pengelompokan, susunan kata-kata dan cara khusus pengungkapan ide sedangkan gaya bahasa dan ungkapan merupakan penyampaian bersifat individual dan khusus dengan karakteristiknya sendiri. Diksi dalam karya sastra merupakan refleksi interpretasi makna sehingga seorang penulis karya sastra harus pandai memilih kata yang tepat. Misalnya, diksi dalam puisi sangat ditentukan oleh kata-kata paling sesuai dalam pengaturan yang tepat (DiYanni, 2001). Diksi merupakan pilihan kata yang digunakan untuk menyampaikan buah pikiran serta gagasan agar dapat sampai seperti yang diinginkan.

Terkait diksi dalam suatu gaya bahasa atau majas, pilihan kata dapat menjadi ciri majas tertentu, contohnya majas pertentangan yang diwakili oleh kata-kata saling berlawanan. Salah satu majas yang menarik ditelaah dari segi diksi adalah oksimoron. Konsep majas oksimoron sangatlah jelas sehingga dapat dikategorikan sebagai gaya bahasa pertentangan. Relasi semantis dalam oksimoron adalah antonim yang ditempatkan dalam suatu hubungan sintaksis berupa koordinasi atau subordinasi (Kridalaksana, 2008).

Oksimoron adalah gaya bahasa yang menjadi suatu acuan dalam menggabungkan kata-kata agar tercapai dampak yang bertentangan. Keraf (2006: 136) menyebutkan oksimoron berasal dari dua kata yaitu okys yang berarti tajam dan moros bermakna gila, tolol. Oksimoron adalah "gaya bahasa yang mengandung pertentangan dengan mempergunakan kata-kata yang berlawanan dalam frasa yang sama. Karena itulah oksimoron bersifat lebih padat dan tajam dari paradoks." Lebih lanjut, contoh-contoh yang diberikan Keraf (2006) memperjelas relasi bertentangan yang sangat jelas melalui diksi-diksi beroposisi seperti beberapa contoh berikut:

(1) Keramah-tamahan yang bengis.

(2) Untuk menjadi manis seseorang harus menjadi kasar.

(3) Dengan membisu seribu kata, mereka sebenarnya berteriak-teriak agar diperlakukan dengan adil.

Contoh di atas memperjelas pertentangan yang terjadi dalam majas oksimoron. Hal ini dapat dilihat dari pilihan kata "keramah-tamahan" yang 
dipertentangkan dengan "bengis," "manis" dengan "kasar" serta "membisu" dan "berteriak-teriak." Dilihat dari relasi semantis, makna beroposisi terjadi dalam majas oksimoron yang jika dikaji lebih lanjut menjadi ranah pembahasan antonim. Cara pengungkapan sesuatu yang berlawanan dalam relasi sintaksis diwakili pada contoh (1) di atas menunjukkan pertentangan terjadi sangat dekat di tingkat frasa sedangkan (2) dan (3) terjadi di tingkat kalimat. Nuansa dan ciri berlawanan ini menjadi menarik dikaji jika hadir dalam puisi sehingga dapat dinilai kemahiran penyair tak hanya mampu menyampaikan ide namun juga bermain kata yang menimbulkan dampak interpretasi mendalam.

Dikaitkan dengan relasi semantis yang terdapat dalam majas oksimoron, pembahasan antonim dan jenis-jenisnya merupakan satu bagian yang tak terpisahkan. Untuk mewakili nuansa bertentangan yang membuat puisi bisa lebih hidup dan menyentuh, kajian pada hubungan makna dan jenis antonim perlu diperhatikan. Secara umum jenisjenis antonim dibedakan berdasarkan interpretasi pada relasi makna berlawanan yang terkandung dalam leksikonleksikonnya (Gao \& Zheng, 2014).

Dilihat dari struktur leksikal dalam leksikon yang mengandung makna bertentangan, hubungan antarkata yang terdapat dalam diksi majas oksimoron adalah antonimi. Konsep antonimi sebagai relasi berlawanan secara umum dapat dilihat dalam lima bentuk oposisi antarkata (Keraf, 2006: 39). Bentuk yang berlawanan tersebut berupa (1) oposisi kembar, (2) oposisi majemuk, (3) oposisi gradual, (4) oposisi relasion- al dan (5) oposisi hirarkis dan (6) oposisi inversi.

Oposisi kembar diwujudkan dalam contoh antara "laki-laki" dan "wanita," "jantan" dan "betina" serta "hidup" dan "mati." Ciri dari oposisi kembar adanya dua anggota yang menunjukkan penyangkalan satu pihak merupakan penegasan terhadap pihak lain. Dalam oposisi kembar "hidup-mati," jika suatu kondisi digambarkan hidup, berarti hal itu "tidak mati." Untuk oposisi majemuk, konsep utama yang menjadikannya bersifat spesifik adalah oposisi yang mencakup suatu perangkat yang terdiri dari dua kata. "Warna" adalah salah satu contoh oposisi majemuk karena jika suatu benda dikatakan berwarna ungu, kata benda tersebut bisa saja bukan putih, merah, hijau dan warnawarna lain selain yang dimaksudkan. Untuk oposisi gradual, kelas ini sebenarnya mengandung suatu penyimpangan dari oposisi kembar, contohnya antara "kaya" dan "miskin", "besar" dan "kecil," "panjang" dan "pendek" dan sebagainya terdapat tingkatan (gradasi) yang bisa diukur, misalnya "sangat panjang" dan "pendek" atau "lebih panjang" dan "pendek." Sedangkan oposisi relasional ditunjukkan dengan contoh "orang tua" dan "anak," "suami" dan "istri," "menjual" dan "membeli." Kriteria lain seperti oposisi hirarkis adalah oposisi yang terjadi karena tiap istilah menduduki derajat yang berlainan seperti ukuran yaitu "millimeter" dan "centimeter," "inci" dan "kaki," dan lain sebagainya. Oposisi inversi merupakan oposisi yang terdapat pada pasangan kata seperti "beberapa" dan "semua", "mungkin" dan "wajib", juga "boleh" dan "harus." 
Kajian penerjemahan puisi sebagai bagian dari penerjemahan sastra (literary translation) melibatkan tak hanya unsur linguistik yang digunakan sebagai wahana dalam menyampaikan ide, pesan dan makna tetapi juga stilistika yang memerlukan imajinasi luas untuk menangkap perenungan yang terdapat dalam puisi. Penerjemahan puisi tak dapat dilepaskan dari keindahan bentuk karya sastra ini sehingga penerjemahan harus memperhatikan konsep detail dan makna, bahkan untuk jenis unit linguistik dari tingkat kata (Newmark, 1988).

Tak hanya puisi yang menjadi media ekspresi seni. Penerjemahan juga adalah seni karena melibatkan kemampuan analisis dan interpretasi makna yang kemudian secara alami dan indah harus disampaikan oleh penerjemah (Jayantini, 2016). Analisis penerjemahan puisi dapat ditinjau dari beragam topik khusus. Beberapa diantaranya berupa kajian yang utuh dalam satu puisi menyangkut unsur ekstratekstual puisi yaitu skemata penyair dan penerjemah, kedekatan puisi bahasa sumber dan hasilnya dalam bahasa sasaran, koherensi serta implikatur (Prihantono, 2014), mitos-mitos dalam penerjemahan puisi menyangkut apakah penerjemahan dilakukan secara setia atau terjadi pengkhianatan (Hariyanto, 2012) Kajian penerjemahan puisi juga dapat dilihat dari strategi penerjemahan dan fungsi performatif yang diciptakan kembali pada puisi bahasa sasaran dapat (Prasetyo, 2018).

Selain itu, kajian penerjemahan puisi bisa mengambil salah satu fokus bahasa figuratif, termasuk citraan (imagery) (Jayantini dan Maharani, 2012), klasifikasi citraan dalam penerjemahan puisi yang bisa juga dinilai tingkat harfiah atau bermaknanya strategi penerjemahan (Jayantini et al, 2017) dan penerjemahan puisi yang menguraikan ragam kesulitan dalam penerjemahan puisi yang meliputi nilai-nilai keindahan dan cara berekspresi, struktur puisi, kolokasi yang mungkin ditemukan, ekspresi melalui metafora yang digunakan hingga bunyi (Temirov, 2012).

Analisis strategi penerjemahan puisi pada penelitian ini dilakukan dengan dasar kategori strategi penerjemahan bahasa figuratif dari (Liu \& Zhang, 2005) yang dibagi menjadi lima. Kelima strategi penerjemahan bahasa figuratif yang disebutkan adalah (1) harfiah (literal translation), (2) penerjemahan makna (meaning translation), (3) penerjemahan harfiah-makna (literal-meaning translation), (4) penerjemahan penggantian (transference translation) dan (5) penerjemahan elipsis (ellipsis translation)

Penerjemahan harfiah (literal translation) mengacu pada penerjemahan yang dilakukan dengan setia pada aspek linguistik dan makna yang ada pada bahasa sumber dan dikatakan secara harfiah dalam bahasa sasaran. Penerjemahan ini dilakukan dengan konsep bahwa ungkapan-ungkapan figuratif dapat memiliki makna dan membawa kesan yang sama tanpa mempertimbangkan latar belakang warna, negara dan budaya. Diyakini bahwa setiap orang di dunia ini berbagi pandangan yang sama dalam rasa, emosi dan halhal yang berkaitan dengan nilai-nilai universal. Berdasarkan semua itu, penerjemahan harfiah dilakukan dengan pertimbangan kesetiaan pada makna yang juga dirasa dapat berterima dengan baik di pembaca bahasa sasaran. Dengan cara ini, seperti dikutip dalam 
(Liu \& Zhang, 2005), penerjemahan tidak hanya berhasil menyampaikan pesan yang disampaikan penulis karya sastra yang menggunakan bahasa figuratif tetapi juga pada saat yang sama me-ngapresiasi aspek-aspek estetis dalam bahasa sumber dan diperkenalkan pada khalayak dalam bahasa sasaran.

Penerjemahan penggantian yang disebut juga "transference" dimaksudkan sebagai penerjemahan penggantian yang mengacu pada pengungkapan dengan menggunakan konteks bahasa sasaran. Contoh yang dapat diajukan dalam penerjemahan ini adalah representasi berbeda yang ada dalam bahasa sumber dan bahasa sasaran. Misalnya seputih salju (as white as snow) dalam karya sastra berbahasa Inggris menjadi seputih kapas dalam versi karya-karya berbahasa Indonesia. Hal ini dapat terjadi karena perbedaan asosiasi yang dihadirkan dalam puisi berbahasa Inggris dan berbahasa Indonesia. Penggantian atau pengalihan ini terjadi karena perbedaan "image" dan "asosiasi" yang muncul dan diperlukan perubahan untuk meningkatkan "aesthetic appreciation."

Penerjemahan makna (meaning translation) ditujukan untuk membuat penerjemahan yang ada sebagai "total distinction of languages" karena penerjemahan harfiah dan penggantian tidak cukup sebagai wahana penyampaian pesan. Dalam beberapa kasus, citraan yang muncul dalam karya sastra tidak dapat digantikan atau diterjemahkan. Untuk tujuan lebih natural, penerjemahan dibuat agar berterima dan terbaca dengan baik sehingga penerjemahan makna ini dipilih.

Penerjemahan literal meaning dilatarbelakangi oleh pendapat sejumlah ahli seperti dikutip dari Benjamin Jowett (dalam Liu \& Xiaobing, 2005) yang menekankan bahwa terjemahan tidak saja harus menjaga "cita rasa" (SL flavor) yang terdapat dalam bahasa sumber tetapi dapat menyampaikan ide dari penulisnya sehingga membuat pembaca dalam bahasa sasaran dapat mengapresiasi nilai-nilai estetis yang ada. Sehingga dalam hal ini, meskipun penerjemahan dilakukan secara harfiah, hasil dari pendekatan yang digunakan adalah usaha mewujudkan keindahan dalam penerjemahan karya sastra, khususnya penerjemahan bahasa figuratif.

Penerjemahan elipsis dimungkinkan terjadi jika ada bahasa figuratif yang memiliki asosiasi sama dan diulang-ulang dalam satu karya sastra. Contoh dalam penerjemahan bahasa figuratif yang menyiratkan nuansa "antithesis" pengulangan pada ungkapan yang sama dan serupa dapat dilakukan dengan cara pengurangan atau "ellipsis" untuk menghindari ungkapan-ungkapan yang sama dan berulang-ulang.

\section{METODE}

Metode dalam kajian ini adalah kualitatif yang diterapkan dengan beberapa langkah dan teknik. Langkah awal dimulai dari melakukan pengamatan (observation) dilanjutkan dengan aktivitas analisis isi (content analysis) yang dilakukan dengan teknik pencatatan (note taking technique). Pengamatan dilakukan dengan pembacaan berulang kali secara teliti dan saksama yang dilengkapi juga membaca referensi mengenai sumber data. Pencatatan dilakukan dengan mencermati secara teliti kemunculan majas pertentangan yang diwakili leksikon-leksikon bertentangan dalam suatu relasi sintaksis. Tabulasi 
data dikerjakan dengan memisahkan baris puisi bahasa sumber dan bahasa sasaran kemudian diksi-diksi yang bertentangan diberi tanda untuk kemudian dikasifikasi dan diamati bentuk terjemahannya. Tahapan analisis mencakup analisis makna dari diksi yang berlawanan dan terjemahannya yang diamati sesuai kecenderungan hasil sesuai dengan teori, terutama strategi penerjemahan.

Sumber data dalam penelitian ini kumpulan puisi bahasa Indonesia terjemahannya dalam bahasa Inggris. Data berupa diksi yang saling berlawanan dan baris-baris puisi yang menjadi bahan analisis untuk interpretasi strategi penerjemahan. Keabsahan proses penelitian dapat dilihat dari penerapan metode dan teknik yang secara signifikan dapat memberikan gambaran data untuk klasifikasi jenis antonim dan strategi penerjemahannya sesuai fokus dari kajian ini. Teks yang dianalisis adalah kumpulan puisi berjudul "Tidak ada New York Hari Ini" yang diterjemahkan ke dalam bahasa Inggris menjadi There is No New York Today karya M. Aan Mansyur dan penerjemahannya oleh John McGlynn terbitan PT Gramedia Pustaka Utama tahun 2016. Kumpulan puisi ini menarik dianalisis karena keunikan gaya bahasa dalam menyampaikan pesan-pesan puisinya. Keindahan puisi karya Mansur terlihat pada diksi yang lugas dan berani sehingga tercipta suasana romantis, manis namun kerap kali terasa sinis seperti sindiran dingin dan suram (gloomy) yang sarat renungan. Misalnya jika citraan "Pagi di Central Park" (salah satu judul puisi dalam antologi) diciptakan, pilihan kata yang digunakan untuk mewujud- kan citraan (imagery) pagi hari di taman yang dimaksud dapat diperoleh secara jelas melalui diksi yang tepat agar bisa dibayangkan nyata oleh pembacanya.

Langkah-langkah yang diterapkan dalam menganalisis penerjemahan puisi dengan fokus majas oksimoron dalam penelitian ini mengacu pada analisis isi (content analysis) dalam karya sastra (Rafiek, 2011). Setelah diperhatikan dengan teliti, bait-bait puisi yang memuat majas oksimoron diklasifikasikan tersendiri dan alasan klasifikasi dicatat dengan saksama. Dari sekian banyak langkah-langkah yang umum diterapkan dalam penelitian sastra, penelitian ini menggunakan sejumlah langkah seperti pengamatan pada sumber data dengan cara membaca hatihati dan cermat, mengumpulkan data, mengamati data yang telah dikumpulkan, dan mencari keterkaitan antara masalah dan analisis, kemudian analisis data dilakukan.

Secara ringkas, langkah-langkah pendahuluan sampai akhir proses untuk mendapatkan pemetaan kategori diksi bertentangan dan strategi penerjemahan majas oksimoron dapat dibagi menjadi (1) meneliti baris demi baris dalam puisi yang menandakan adanya suasana berlawanan dan diwakili oleh diksi yang beroposisi, (2) klasifikasi dilakukan sesuai dengan antonim yang ditemukan dalam puisi bahasa sumber (Indonesia) dan puisi bahasa sasaran (Inggris) untuk melihat kecenderungan strategi penerjemahan, (3) analisis dilakukan dengan membahas makna yang saling beroposisi dan meneliti hasil terjemahannya sehingga pemetaan pada tingkat kata yang mewakili majas oksimoron dapat dipetakan. 


\section{HASIL DAN PEMBAHASAN \\ Hasil}

Penerjemahan diksi dalam majas oksimoron tak dapat dilepaskan dari klasifikasi penting yang melibatkan jenis antonim dan penerjemahan puisi. Adapun klasifikasi tersebut dapat digambarkan sebagai berikut:
1. Klasifikasi pertama adalah jenis antonim yang ditemukan untuk mewakili suasana bertentangan sehingga dapat disebut sebagai majas oksimoron yang menempatkan leksikon-leksikon beroposisi dalam suatu relasi sintaksis seperti ditunjukkan dalam tabel 1 .

Tabel 1. Jenis Antonim

\begin{tabular}{clcl}
\hline No & Jenis Antonim & Jumlah & \multicolumn{1}{c}{ Contoh } \\
\hline 1 & Oposisi Kembar & 7 & $\begin{array}{l}\text { "kesedihan" dan "kebahagiaan," "kenangan" dan "masa } \\
\text { depan," }\end{array}$ \\
2 & Oposisi Gradual & 4 & "panjang" dan "pendek" \\
3 & Oposisi Relasional & 4 & "bicara" dan "mendengar." \\
\hline & TOTAL & $\mathbf{1 5}$ & \\
\hline
\end{tabular}

Diksi yang ditemukan dalam majas oksimoron kumpulan puisi "Tidak ada New York Hari ini" ditinjau dari klasifikasi antonim dalam relasi enam jenis oposisi (Keraf, 2006). Penelitian ini menemukan beberapa jenis antonim yang beroposisi dalam tiga bentuk yaitu (1) oposisi "kembar" dalam bahasa Indonesia yang terdapat dalam "kesedihan" dan "kebahagiaan," juga "kenangan" dan "masa depan," dan (2) oposisi gradual dalam "panjang" dan "pendek" juga (3) oposisi relasional seperti "bicara" dan "mendengar,"

2. Strategi penerjemahan diksi majas oksimoron yang ditemukan ada dua kategori yaitu penerjemahan harfiah dan penerjemahan harfiahmakna. Jumlah yang muncul hampir beimbang antara kedua strategi yang muncul ini seperti terlihat pada tabel 2 .

\section{Tabel 2 Strategi Penerjemahan}

\begin{tabular}{|c|c|c|c|}
\hline No & Jenis Antonim & Jumlah & Contoh \\
\hline 1 & Penerjemahan Harfiah & 8 & $\begin{array}{l}\text { "kesedihan" dan "kebahagiaan," "kenangan" } \\
\text { dan "masa depan," }\end{array}$ \\
\hline \multirow[t]{2}{*}{2} & Penerjemahan Harfiah-Makna & 7 & "panjang" dan "pendek" \\
\hline & TOTAL & 15 & \\
\hline
\end{tabular}

Kedua strategi penerjemahan ini mengacu pada (Liu \& Zhang, 2005) yang memetakan penerjemahan baha- sa figuratif menjadi 5 yaitu (1) harfiah (literal translation), (2) penerjemahan makna (meaning translation), (3) pener- 
jemahan harfiah-makna (literal-meaning translation), (4) penerjemahan penggantian (transference translation) dan (5) penerjemahan elipsis (ellipsis translation).

\section{Pembahasan}

Sesuai fokus penelitian yang ditekankan pada jenis antonim dan strategi penerjemahan diksi yang beroposisi dalam makna, pembahasan secara lengkap dibagi menjadi dua bagian. Pertama, antonim yang muncul dijelaskan jenis, jumlah dan contoh penggunaannya dalam baris-baris puisi. Penyajian sejumlah perwakilan data ditujukan untuk memperlihatkan suasana bertentangan yang dibangun antonim dengan klasifikasi yang berbeda sehingga derajat pertentangan juga dapat dirasakan nuansanya. Kemunculan jenis antonim yang berbeda dapat membantu pembaca membayangkan gambaran suasana yang dipertentangkan dan menginterpretasi maksud puisi. Kedua, strategi penerjemahan dianalisis dengan cara memberikan contoh penerapannya pada karya terjemahan puisi. Dua strategi penerjemahan yang digunakan adalah harfiah dan harfiah-makna. Penerjemahan harfiah berarti bahwa penerjemahan dilakukan dengan menggunakan padanan yang makna leksikal yang sudah umum diketahui dan mudah ditebak karena memang demikianlah padanannya dalam bahasa sasaran. Penerjemahan harfiah-makna adalah penerjemahan yang dilakukan dengan menggunakan padanan alternatif lebih idiomatik. Hal ini ditujukan untuk memberi sentuhan estetis dan puitis pada hasil terjemahan.

\section{Jenis Antonim}

Jenis antonim yang ditemukan dalam antologi puisi "Tidak Ada New York Hari Ini" menunjukkan bahwa relasi pertentangan memiliki klasifikasi tersendiri. Kategori yang muncul secara terpisah memberi gambaran keberagaman diksi dan tingkat pertentangan yang muncul dalam menggali kesan berlawanan dan mewakili pesan yang ingin disampaikan dalam puisi. Oposisi antonim yang ditemukan ada dalam tiga bentuk yaitu (1) oposisi kembar yang ditemukan dalam "kesedihan" dan "kebahagiaan,"juga "kenangan" dan "masa depan," (2) oposisi gradual terdapat pada diksi "panjang" dan "pendek" dan (3) oposisi relasional yang diwakili dalam pilihan kata "bicara" dan "mendengar,"

\section{Oposisi Kembar}

Oposisi jenis ini menunjukkan pertentangan mutlak dari dua leksikon, misalnya "hidup" dan "mati" yang merupakan kenyataan bertentangan tak terbantahkan. Oposisi kembar dalam antologi puisi ini dapat disimak pada kutipan kalimat puisi /Meletakkan jiwaku di antara keinginan dan keengganan kembali/, di antara perkara-perkara yang mungkin dan tidak mungkin selesai/. Baris puisi ini diterjemahkan menjadi / Posits my soul between a longing and a reluctance to return/, between things that might possibly be resolved and other things that can never be/. Diksi "keinginan" dan "keengganan" dapat disebut memiliki relasi makna bertentangan mutlak karena kuat tergambarkan pertentangan antara rasa "ingin" tapi ada juga "enggan." Dua hal yang berlawanan ini digunakan untuk menggambarkan pertentangan 
yang sering kali terjadi dalam kehidupan. Seseorang bisa mempunyai "keinginan" sebagai rasa yang menggebu untuk menggapai sesuatu tetapi bisa muncul "keengganan' yang merupakan perasaan malas sebagai kondisi beroposisi mutlak.

\section{Oposisi gradual}

Oposisi gradual dapat diwakili leksikon bertentangan yang memberikan suasana gradasi terukur. Contoh oposisi jenis ini dapat ditemukan pada pemakaian kutipan puisi / Jendela terbuka dan masa lampau memasukiku sebagai angin. Meriang. Meriang. Aku meriang. Kau yang panas di kening. Kau yang dingin dikenang/. Baris-baris ini diterjemahkan menjadi / Through the open window the past enters me like wind. I shiver. Shiver. Shiver. You are the fever in my mind, you are the frost in my memory/. Oposisi gradual dalam nukilan puisi ini diwakili oleh diksi "panas" dan "dingin" yang diterjemahkan secara harfiah-makna dengan pilihan diksi "fever" dan "frost." Dalam diksi beroposisi "panas" dan "dingin" ditemukan kemungkinan perbandingan hirarkis seperti "lebih panas", "paling panas" atau "lebih dingin" dan "paling dingin." Dengan interpretasi kemungkinan oposisi yang dapat dikembangkan dengan memberi perbandingan, dua adjektiva ini diklasifikasikan dalam oposisi gradual yang secara konteks diterjemahkan dengan menafsirkan makna lebih adaftif sehingga tidak langsung menjadi hot dan cold tetapi disesuaikan dengan kebutuhan citraan dalam puisi sehingga menjadi fever dan frost.

\section{Oposisi Relasional}

Antonim yang mempunyai makna relasional adalah oposisi yang memiliki kaitan hirarkis. Dalam antologi puisi yang dibahas, selain menggunakan oposisi kembar dan gradual, penyair juga menggambarkan pertentangan yang saling terhubung dengan peran yang berbeda. Contoh dalam relasi waktu yang digambarkan pada baris puisi berjudul "Batas" (Borders). /Semua perihal diciptakan sebagai batas/. Membelah sesuatu dari sesuatu yang lain./ Hari ini membatasi besok dan kemarin/. Besok batas hari ini dan lusa/. Terjemahan untuk baris puisi ini adalah / Everything in creation has borders / which set apart one thing from another/. Today's borders are yesterday and tomorrow/; tomorrow's borders are today and the day after/. Diksi yang terhubung dengan relasi waktu antara "besok" dan "kemarin" ini memperlihatkan oposisi yang terhubung dengan peran masing-masing. Peran yang ada dalam "besok" dan "kemarin" yang diterjemahkan secara harfiah menjadi yesterday dan tomorrow adalah peran penunjuk waktu antara yang sudah berlalu (kemarin) dan yang akan datang (besok). Relasi waktu dengan perannya sendiri-sendiri ini menjadi dasar pertimbangan klasifikasi pada oposisi relasional.

\section{Strategi Penerjemahan}

Strategi penerjemahan diksi majas oksimoron dapat dilihat dari kutipan bagian-bagian puisi yang telah diklasifikasikan mengandung makna berlawanan dan secara langsung diwakili oleh diksi beroposisi. Selain difokuskan pada penerjemahan antonim yang digunakan sebagai pilihan kata dalam majas oksimoron, analisis penerjemahan juga 
dilengkapi dengan interpretasi terhadap tema puisi secara utuh sehingga mendukung analisis terhadap diksi yang digunakan. Berikut adalah penjelasan strategi penerjemahan yang diterapkan dalam menerjemahkan diksi majas oksimoron dalam antologi puisi "Tidak ada New York hari ini" yang diterjemahkan menjadi "There is no New York Today."

\section{Penerjemahan Harfiah}

Penerjemahan harfiah dapat dilihat pada beberapa contoh berikut:

(1) Jarak antara kenangan dan masa depan ialah keterpisahan laut dan kalut di dada yang berusaha tidak meluap di mata (Mansyur, 2016: 34)

The distance between memory and the future is the gap between the sea and storm in your chest that threatens to well over in your eyes (McGlynn dalam Mansyur, 2016: 35).

Dari kutipan puisi (1) di atas, dapat dilihat bahwa oposisi yang digunakan adalah oposisi kembar dalam bahasa Indonesia yang ditunjukkan adanya pemakaian "kenangan" dan "masa depan." Oposisi ini terjadi dalam nuansa pertentangan yang bercirikan penyangkalan terhadap satu aspek berarti penegasan pada aspek lain. Hal ini nampak pada pertentangan antara "kenangan" dan "masa depan" yang merupakan lawan nyata dari keduanya. Jika kenangan merupakan warisan masa lalu atau lampau, maka kenangan tak akan hadir di masa depan. Hanya saja, dari segi makna secara leksikon, oposisi kembar ini memerlukan interpretasi lebih lanjut sesuai penempatannya dalam kalimat. "Kenangan" digunakan dalam konteks ini oleh penulis untuk memberikan penekanan bahwa hal yang dimaksud tidak hanya sekadar "masa lalu" (sebagai lawan kata masa depan) tetapi sebuah kenangan yang melibatkan perasaan lebih mendalam. "Kenangan" memiliki komponen makna yang lebih khusus dari "masa lalu" dengan perbedaan pada ingatan lebih mendalam yang ditinggalkan oleh suatu kejadian di masa lampau. Dapat dipula diberikan interpretasi bahwa setiap orang memiliki masa lalu namun belum tentu seluruhnya menjadi kenangan. Kenangan dipilih dalam puisi ini untuk mewakili perasaan hidupnya peristiwa yang ada di masa lampau dan tak terhapus dari ingatan sang pemilik kenangan.

Kedua antonim ini merupakan diksi majas oksimoron yang terdapat dalam puisi berjudul "Di Tempat Jauh Tak Ada Masa Lalu" yang mengungkap rasa frustasi penutur puisi tentang ketidakbersahabatan hidup dengan adanya peristiwa-peristiwa di masa yang sudah lewat seperti terlukis dalam perumpamaan di bait pertama puisi, "Tidak ada masa lalu/Hidup adalah musuh/ Kau bangun menemukan hari yang ingin kauhapus menunggu di dekat pintu, seperti sepasang sepatu yang harus kaukenakan ke tempat kerja/...."

Majas oksimoron dalam puisi ini terdapat secara jelas pada bait ketiga puisi yang diungkap seperti ini /Di tempat jauh tidak ada masa lalu/Jarak antara kenangan dan masa depan/ialah keterpisahan laut dan kalut di dada/ yang berusaha tidak meluap di mata. Tapi kau/ tidak pernah tahu: siang ini langit akan baik-baik/ saja atau badai datang menyerang sekali lagi/ Kau tidak pernah tahu. Terjemahan dari bait ini ada- 
lah / In far-away places there is no past/ The distance between memory and the future/ is the gap between the sea and storm in your chest/ that threatens to well over in your eyes/. You never know: today the sky might come out or a storm will trounce you once again. / You just never know.

Penerjemahan diksi majas oksimoron dalam penggalan puisi tersebut adalah penerjemahan harfiah karena memory yang berarti "something remembered from the past." (https:// en.oxforddictionaries.com/definition/ memory) diterjemahkan menjadi kenangan yang dalam KBBI Daring dijelaskan sebagai "sesuatu yang membekas dalam ingatan; kesan." (https:// kbbi.web.id/kenang. Demikian juga pada lawan katanya masa depan diterjemahkan menjadi future yang sama-sama dimaksudkan merujuk pada suatu masa atau waktu yang akan datang.

Penerjemahan kedua diksi dalam bahasa sumber yaitu kenangan dan masa depan dalam kutipan puisi tersebut dilakukan secara harfiah karena terjemahannya yaitu memory dan future merupakan padanan baku, artinya padanannya memang terdapat dalam kamus dan disesuikan dengan pengetahuan seseorang mengenai kosakata dan makna diksi yang digunakan.

(2) Aku ingin hidup di jantung kata itu sebagai kesedihan hampa yang jauh lebih berat dari seluruh kebahagiaan yang mampu manusia terima (Mansyur, 2016: 60)

I want to live in the heart of that word in the form of a hollow and distant sadness which is heavier than all the happiness a person could possibly accept (McGlynn dalam Mansyur, 2016: 61)
Kutipan puisi (2) yang mengandung majas oksimoron di atas merupakan bait kedua dari puisi berjudul "Kesedihan Puisi" yang diterjemahkan menjadi "Poetry's Sadness." Oposisi yang muncul dalam kesedihan dan kebahagiaan adalah oposisi kembar yang menyiratkan pertentangan nyata atau mutlak dari keduanya. Hal sentral yang menjiwai puisi ini adalah keberadaan puisi yang digunakan untuk mendeskripsikan suatu kesedihan yang dapat terlihat dari bait awalnya yaitu /Puisi ini butuh satu kata/ yang belum pernah menyentuh/ pikiran dan lidah siapapun\% tapi/ kau mengerti artinya. Hanya kau/. Bait pertama ini diterjemahkan menjadi / This poem is in need of a word/ which has never before appeared in the mind/ or on the tongue of anyone\% but one whose meaning/ only you understand. Only you/. Secara fisik dan gaya bertutur, penerjemahan yang dilakukan tidak banyak bergeser dari unsur fisik puisi. Hal ini dapat dilihat dari kata-kata dalam terjemahannya yang merupakan padanan baku dari masing-masing diksi dalam bait puisi ini.

Diksi majas oksimoron dalam puisi ini terlihat sangat jelas pada / Aku ingin hidup di jantung kata itu/ sebagai kesedihan hampa yang jauh/ lebih berat dari seluruh kebahagiaan/ yang mampu manusia terima yang diterjemahkan menjadi I want to live in the heart of that word/ in the form of a hollow and distant sadness / which is heavier than all the happiness/ a person could possibly accept. Dari kedua kutipan puisi di atas, dapat dilihat diksi majas oksimoron dalam antonim "kesedihan" dan "kebahagiaan" yang merupakan oposisi kembar.

Oposisi kembar "kesedihan" dan "kebahagiaan" ini diterjemahkan se- 
cara harfiah yang bersifat padanan baku kedua diksi dalam bahasa Inggris yaitu "sadness" dan "happiness." Kedua bentuk juga tak mengalami pergeseran unit linguistik, keduanya merupakan nomina abstrak untuk menggambarkan keadaan yang saling bertentangan dan menjadi bagian penting dari pernyataan yang digunakan oleh penyair.

\section{Penerjemahan Harfiah-Makna}

Penerjemahan harfiah-makna ini ditemukan pada tiga baris pada puisipuisi dalam antologi yang sedang diteliti. Kriteria harfiah-makna ini didasarkan pada adanya pendekatan yang bersifat lebih membuat puisi mempunyai makna interpretatif. Dalam hal ini, makna yang muncul dalam padanan yang dipilih bisa lebih khusus (particular) atau umum (general) yang dimaksudkan agar diksi dalam bahasa sasaran dapat mencapai citraan yang bersifat lebih alami.

(3) Ketika kau bertanya padaku tentang cinta, aku melihat nasib manusia. Terkutuk hidup di bumi bersama jangkauan lengan mereka yang pendek dan kemauan mereka yang panjang (Mansyur, 2016: 16)

When you asked me about love, I saw the fate of humankind. Accursed beings with a too-short arm span and toolengthy desires (McGlynn dalam Mansyur, 2016: 17)

Kutipan pada (3) terdapat dalam puisi berjudul "Ketika Kau Bertanya Tentang Cinta" ini merupakan contoh penerapan majas oksimoron dengan diksi yang beroposisi gradual yaitu "pendek dan panjang." Oposisi gradual menurut (Keraf, 2006:40) menunjukkan pertentangan yang mutlak dan memang demikian adanya. Diksi "pendek" dan "panjang" dapat juga diklasifikasikan selain memiliki kemutlakan pertentangan bahwa lawan kata "pendek" adalah "panjang," (Hu dalam Gao \& Zheng, 2014) menyebutkan lawan kata ini juga dapat diklasifikasikan sebagai gradable antonimy seperti contoh lainnya yaitu hot/cold, big/small and tall/short yang memiliki jenjang-jenjang dalam pengukuran.

Dilihat dari terjemahannya, diksi "pendek" dan "panjang" yang mewakili konsep oksimoron berupa pertentangan dalam satu relasi sintaksis yang dalam hal ini terlihat dari keterhubungan frasa dalam kalimat "Terkutuk hidup di bumi bersama jangkauan lengan mereka yang pendek dan kemauan mereka yang panjang" yang diterjemahkan "When you asked me about love, I saw the fate of humankind. Accursed beings with a too-short arm span and too-lengthy desires." Dilihat dari penerjemahan "jangkauan lengan mereka yang pendek" menjadi "a too-short arm span" serta "kemauan mereka yang panjang" menjadi "too-lengthy desires."

Penerjemahan diksi "pendek" menjadi "too short" dan panjang menjadi "too-lengthy" menunjukkan adanya gradasi yang dimungkinkan melalui penambahan adverbial "too" untuk membentuk frasa adjektiva yang lebih greget dan hidup (vivid) dalam menciptakan suasana pertentangan pada puisi terjemahannya. Dalam kondisi seperti ini penerjemahan diksi yang merupakan antonim beroposisi gradual dapat dikategorikan sebagai penerjemahan harfiah-makna. Kesan harfiah masih ada ketika diksi berlawanan "pendek" dan "panjang" diterjemahkan "short" dan "lengthy" yang kemudian dibuat 
lebih bermakna dengan penambahan "too (sangat atau terlalu) "sesuai karakteristik stilistika bahasa sasaran agar kesan yang diciptakan lebih mengena dan kuat.

(4) Aku seperti menyalami kesedihan lama yang hidup bahagia dalam pelukan puisi-puisi Pablo Neruda (Mansyur, 2016: 20)

I seem to be greeting an old sadness, one that lives with ease in the embrace of Pablo Neruda's poetry ( McGlynn dalam Mansyur, 2016: 21)

Kutipan puisi (4) di atas diambil dari puisi berjudul "Pagi di Central Park" dalam antologi yang sedang dibahas ini. Puisi berlatar pagi dan Central Park terdiri dari dua bait dan yang mengandung majas oksimoron adalah barisbaris di bait kedua. Kutipan bait pertama yang dapat digunakan sebagai pembuka munculnya diksi beroposisi sebagai ciri khas majas oksimoron adalah /Pagi di Central Park. Ada serimbun semak/ sedang berbunga. Berembun dan merekah/. Di dekatnya, di bangku taman, duduk tertidur/ seorang gelandangan $\%$ /merengkuh tubuh ringkih sendiri/ Aku tidak tahu nama mereka/. Barisbaris ini diterjemahkan menjadi Morning in Central Park. Bowers of bushes/ are now in bloom/ Flowers are covered in dew/. On a park bench nearby, a homeless man/is slumped in sleep \% moaning as he clings/ to himself. I do not know their names.

Puisi yang terdiri dari dua bait ini diawali dengan suasana pagi yang kurang bahagia dan tidak sepenuhnya ceria. Meski tertangkap ada citraan berupa embun dan semak-semak yang berbunga, pemandangan kontras akan terasa ketika di sebuah bangku taman seorang gelandangan duduk tertidur yang digambarkan merengkuh tubuh ringkih sendiri. Suasana bertentangan telah diawali sebelum masuk pada bait kedua yang sangat jelas menggunakan majas oksimoron seperti terdapat dalam kutipan berikut / Aku seperti menyalami kesedihan lama/ yang hidup bahagia dalam pelukan puisi-puisi/ Pablo Neruda. Aku bagai menyelami/ sepasang kolam yang dalam dan diam/ di kelam wajahmu. Terjemahan untuk bagian yang menggunakan majas oksimoron ini adalah $I$ seem to be greeting an old sadness/, one that lives with ease in the embracel of Pablo Neruda's poetry. I seem immersed in the pair of deep and silent pools / looming in the gloom of your face.

Dalam penerjemahan yang ditunjukkan kutipan puisi (4), diksi "kesedihan" dipertentangkan dengan "bahagia." Dalam hal ini bukan "kebahagiaan" yang digunakan tetapi "hidup bahagia." Klasifikasi oposisi gradual untuk diksi bahasa Indonesia "sedih dan bahagia" sesuai dengan sifat gradasi berlawanan yang ada dalam kedua adjektiva ini. Klasifikasi "sad" dan "happy" sebagai padanan "sedih" dan "bahagia" sebagai gradable antonymy dalam bahasa Inggris memiliki potensi untuk dideskripsikan dalam tingkatan. Misalnya "good" dan "bad" yang sama-sama memiliki bentuk komparatif (comparative) yaitu "better" dan "worse" dan superlatif yang diwujudkan dengan "worse" dan "worst." (superlative).

Penerjemahan ungkapan "Aku seperti menyalami kesedihan lama yang hidup bahagia dalam pelukan puisipuisi Pablo Neruda menjadi "I seem to be greeting an old sadness, one that lives with ease in the embrace of Pablo Neruda's poetry" menunjukkan unsur gabung- 
an antara penerjemahan harfiah dan makna. Strategi penerjemahan ini dapat diamati dari hasil terjemahan yang mencoba untuk memberikan nuansa tambahan dan makna yang lebih mendalam untuk menciptakan cara tertutur lebih komunikatif dalam puisi. Dengan cara ini, hasil terjemahan yang bernuansa bertentangan dapat dibuat lebih alami seperti kondisi si "aku" dalam baris puisi yang menyalami kesedihan lama yang hidup bahagia dalam pelukan puisi-puisi Pablo Neruda. Diksi majas oksimoron terlihat sangat jelas dengan bertentangan "sedih" dan "bahagia." Penerjemah tidak menerjemahkan "yang hidup bahagi" secara mutlak atau harfiah yaitu "that lives happily" tetapi lebih memberikan nuansa gaya bertutur puisi dalam bahasa sasaran yang lebih natural sehingga menjadi "that lives with ease." Ini sekaligus juga memberikan keindahan bunyi yang bermelodi antara "ease" dan "embrace" dalam "in the embrace of Pablo Neruda's poem."

Contoh penerjemahan ini menunjukkan suatu pemetaan bahwa diksi majas oksimoron bisa diterjemahkan dengan cara yang lebih memberikan nilai alami dan berterima bagi sebuah karya sastra. Seperti diketahui, karya sastra terlebih puisi bersifat sarat akan syarat estetika selain kelugasan dalam bertutur kata dari seorang penulis puisi.

(5) Aku bicara perihal segala, tetapi kau tidak mendengar apa-apa (Mansyur, 2016: 56)

Whatever it is I choose to talk about you don't want to listen. You think, but I cannot feel the beat of my own heart.
(McGylnn dalam Mansyur, 2016: 57)

Kutipan puisi (5) secara jelas menunjukkan penggunaan diksi oksimoron melalui pilihan ekspresi yang menunjukkan pertentangan dalam "bicara" dan "mendengar" yang diterjemahkan menjadi "talk" dan "listen." Ungkapan berlawanan ini dikutip dari puisi berjudul "Di Depan Lemari Pendingin" yang diterjemahkan menjadi "Inside the Fridge." Nuansa bertentangan yang menjadi jiwa dari puisi ini secara keseluruhan merupakan hal yang telah diperkenalkan pada dua bait bagian dari puisi ini.

Bait pertama secara lengkap terdiri dari ungkapan seperti ini: / Ada waktuwaktu tertentu saat langit/ melihat semata ada aku berjalan sendiri/ ke mana-mana. Aku bicara perihal segala,/ tetapi kau tidak mendengar apa-apa./ Kau berpikir, tetapi aku tidak bisa merasakan detak jantungku sendiri./ Puisi ini diterjemahkan menjadi / There are certain times when the sky/ sees only me, wandering by myself, alone. / Whatever it is I choose to talk about/ you don't want to listen. / You think, but I cannot feel/ the beat of my own heart.

Ungkapan pada baik kedua puisi ini juga mendukung suasana berlawanan yang kemudian secara lugas dapat diwakili oleh diksi-diksi dan ekspresi yang tak senada. Ungkapan pada baik kedua secara lengkap terungkap seperti ini: /Ada saat kau menemukan cinta/ adalah umbi-umbian di lemari pendingin./ Mereka tiba-tiba bertunas meskipun sudah/ lama lupa rupa dan aroma tanah./ Terjemahannya disajikan dengan ungkapan / When was it that you discovered/ love is that old potato inside 
the fridge, / suddenly starting to sprout/ long after the feel and scent of the soil are gone?/

Dari kedua bait puisi yang disajikan, ada dua nuansa berlawanan yang dapat dianalisis. Pertama, puisi ini menyuratkan pertentangan melalui diksi yang beroposisi seperti bicara dan mendengar. Hal ini ditunjang juga dengan pemanfaatan konjungsi "tetapi" pada bait pertama dan klausa konsesif dengan penggunaan konjungsi konsesif "meskipun" yang terdapat pada baik kedua. Hal kedua yang menunjukkan pertentangan adalah pesan yang disiratkan pada bait pertama dan kedua. Kedua bait puisi "Di Depan Lemari Pendingin" menyiratkan adanya pesan yang tak seimbang, ketimpangan antara satu kondisi dengan kondisi yang lain. Misalnya pada bait pertama ada pihak yang seharusnya bertindak sebagai pedengar ketika ada yang berbicara, namun itu tak dapat terjadi. Demikian pula situasi yang digambarkan pada bait kedua, umbi-umbian yang seharusnya tumbuh dan hafal aroma tanah, harus mendapati kondisi dingin dan mengeluarkan tunasnya di lemari pendingin.

Dari segi diksi dalam puisi dan kategori antonim, "bicara" dan "mendengar" disebut mempunyai keterkaitan. Jika ada seseorang yang berbicara, harapannya tentu ada pihak lain yang "mendengar." Pilihan bertentangan yang memiliki kaitan disebut sebagai oposisi relasional dalam bahasa Indonesia. Untuk terjemahan kedua kata tersebut yaitu "talk" dan "listen" dapat dikategorikan sebagai complementary antonimy karena "talk" (bicara) dan "listen" (mendengar) memiliki kriteria yang berbeda dengan pengujian pada gradable antonimy. Pengujian pada tingkat perbandingan "comparative" dan "su- perlative" digunakan untuk menunjukkan kondisi bertingkat dalam diksi berlawanan. Contohnya sejumlah adjektiva yang menunjukkan keadaan, sebutlah "cepat" dan "bahagia" yang dapat dikondisikan menjadi "lebih cepat," "paling cepat" atau "lebih bahagia" dan "paling bahagia" yang mempunyai terjemahan dalam bahasa Inggris menjadi "faster" dan "fastest" juga "happier" dan "happiest."

Penerjemahan yang dilakukan adalah harfiah-makna yang dilihat dari konteks penerjemahan secara keseluruhan dalam bait puisi yang menggunakan diksi mewakili majas oksimoron dalam kutipan puisi (5) berupa / Aku bicara perihal segala, tetapi kau tidak mendengar apa-apa / Whatever it is I choose to talk about you don't want to listen. You think, but I cannot feel the beat of my own heart. Pada kutipan (5), "bicara" dan "mendengar" sebagai diksi majas oksimoron diterjemahkan juga dengan strategi penerjemahan harfiahmakna. Hal ini dapat dilihat pada Penerjemahan harfiah-makna terlihat dari interpretasi yang diinisiasi oleh penerjemah dalam memberikan makna yang lebih jelas pada pilihan ekspresi bicara tentang segala hal namun tak didengarkan lawan bicara.

Interpretasi berdasarkan konteks yang diperlukan untuk melukiskan suasana bertentangan dari oposisi relasional antara "bicara" yang diterjemahkan "talk" dan "mendengar" menjadi "listen." Penerjemahan harfiah terdapat dalam penerjemahan kedua leksikon bahasa Indonesia yang ada dalam bait puisi ini seperti yang dijelaskan bahwa masing-masing antonim diterjehakan dengan padanan baku yang telah terda- 
pat dalam kamus sebagai makna denotatif masing-masing.

Untuk penerjemahan makna, ungkapan yang mendukung diksi "bicara" dan "mendengar" diterjemahkan secara makna (meaning) dengan mempertimbangkan bicara dan mendengar apa yang diinginkan si "Aku" yang didekripsikan sang penyair. Hal ini dapat dilihat pada baris-baris / Aku bicara perihal segala, tetapi kau tidak mendengar apa-apa / Whatever it is I choose to talk about you don't want to listen. You think, but I cannot feel the beat of my own heart. Dalam kutipan ini dapat dilihat bahwa penerjemahan "bicara perihal segala" tidak semata-mata menjadi "talk about everything" namun disajikan dengan lebih indah menjadi "Whatever it is I choose to talk about." Demikian pula ketika ada pengungkapan "tetapi kau tidak mendengar apa-apa" diterjemahkan secara bermakna dengan you don't want to listen. Kesan pendekatan pada esensi yang tak semata-mata menyerahkan pada penafsiran harfiah dapat mempertegas perasaan yang ingin diungkapkan si "Aku" dan penyair yang mengungkapkan ketidakpedulian si "Kamu" yang diajak berbicara sebagai seseorang yang tidak ingin mendengar (do not want to listen).

\section{SIMPULAN}

Penerjemahan diksi majas oksimoron melibatkan pemetaan relasi oposisi yang ada dalam mengungkapkan atmosfir pertentangan. Selain itu pemetaan juga dilakukan pada strategi yang digunakan penerjemah ketika menyampaikan makna di balik suasana yang terbangun dalam majas oksimo- ron pada kumpulan puisi "Tidak Ada New York Hari Ini." Secara lebih jelas, klasifikasi tersebut dapat diuraikan sebagai berikut:

1. Jenis antonim beroposisi ada tiga yang dapat diklasifikasi menjadi (1) oposisi "kembar" yang ditemukan dalam diksi "kesedihan" dan "kebahagiaan," juga "kenangan" dan "masa depan," (2) oposisi gradual dalam diksi "panjang" dan "pendek" serta (3) oposisi relasional seperti "bicara" dan "mendengar."

2. Penerjemahan diksi majas oksimoron yang ditemukan adalah penerjemahan harfiah dan penerjemahan harfiah-makna. Strategi penerjemahan pada diksi majas oksimoron yang dipilih untuk mewakili suasana bertentangan pada sejumlah puisi menyiratkan kuatnya suasana berlawanan yang membangkitkan nilai-nilai ekspresif dalam puisi.

Hasil kajian penerjemahan diksi dalam majas oksimoron menjadi penting untuk memberi kontribusi pada upaya pemetaan penerjemahan diksi dalam bahasa figuratif tertentu. Hal ini dapat memberi gambaran teoritis mengenai sejauhmana nuansa yang ingin diperkenalkan dalam suatu puisi yang dialihkan dari bahasa Indonesia ke dalam bahasa Inggris. Secara praktis, temuan penelitian dapat memberi deskripsi tentang fenomena kebahasaan yang terjadi di tingkat kata dan berimplikasi pada keseluruhan pesan sehingga para penerjemah dapat mengupayakan penerjemahan yang tepat serta akurat namun juga bersifat alami dan tetap membawa keindahan puisi pada pembaca target. 


\section{UCAPAN TERIMA KASIH}

Ucapan terima kasih penulis tujukan kepada teman-teman sejawat di Sekolah Tinggi Bahasa Asing (STIBA Saraswati Denpasar) yang telah menjadi mitra diskusi dalam rangka pendalaman analisis pada kajian ini.

\section{DAFTAR PUSTAKA}

DiYanni, R. 2001. Literature: Reading Fiction, Poetry and Diction. New York: McGraw-Hill.

Gao, C., \& Zheng, Q. 2014. A Linguistic Study of Antonymy in English Texts. Journal of Language Teaching and Research, 5(1), 234-238. https:// doi.org/10.4304/j1tr.5.1.234-238

Hariyanto, S. 2012. Pengkhianatan demi Kesetiaan: Upaya Masuk Akal Untuk Mencapai Terjemahan Puisi Ideal. Jurnal Linguistik Terapan, (May 2012). Retrieved from https://www. printfriendly.com/p/g/mFUYTE

Jayantini, S. R., Dian L., Ni Luh P., Megantara, I. G. 2017. The Creation of Imagery Trough Poetic Diction in Poetry Translation: Literal or Idiomatic? In The 6th English Language Teaching, Literature and Translation International Conference. Semarang: Universitas Negeri Semarang. Retrieved from http:// proceedings.id/index.php/eltlt/article/view/654/0

Jayantini, S. R., Maharani, S. A. I. 2012. Imagery in Poetry Translation: Are Images Transferred or Translated. In 2nd International Conference on Translation and Interpretation Studies (Transcon 2012). Jakarta: Unika Atmajaya Jakarta.

Jayantini, S. R. 2016. The Art of Translating: Theory and Analysis. Denpasar: Cakra Press.
Keraf, G. 2006. Diksi dan Gaya Bahas. Jakarta: PT Gramedia Pustaka Utama

Kridalaksana, H. 2008. Kamus Linguistik. Jakarta: PT Gramedia Pustaka Utama.

Liu, Q., \& Zhang, C. 2005. Towards the Translation of Figurative Language, 1(1), 122-126. Retrieved from http://www.cscanada.net/ index.php/css/article/viewFile/j. css.1923669720050101.022/102

Mansyur, M. A. 2016. Tidak Ada New York Hari Ini. Jakarta: PT Gramedia Pustaka Utama.

Newmark, P. 1988. A Textbook of Translation. London: Prentice Hall International.

Prasetyo, A. B. 2018. Strategi dan Fungsi Performatif dalam Penerjemahan Puisi Salju. In I. N. Sudipa (Ed.), Buku Persembahan untuk Frans I Made Brata memasuki masa purnabhakti (pp. 51-70). Denpasar: Swasta Nulus.

Prihantono, K. D. 2014. Analisis Penerjemahan Puisi "I Hear America Singing" Karya Walt Whitman: Sebuah Kajian, 173-186. https://doi.org/http://dx.doi. org/10.26610/metasastra.2014. v7i2.173-186

Rafiek, M. 2011. Metode and Teknik Penelitian Sastra. Banjarmasin. Retrieved from http://eprints.ulm. ac.id/366/1

Temirov, M. M. 2012. Difficulties in Poetry Translation. Jurnal Linguistik Terapan, (October 2012). Retrieved from https://www.printfriendly. $\mathrm{com} / \mathrm{p} / \mathrm{g} / \mathrm{hgFzAm}$ 